\title{
医療由来放射性廃裹物の保管・処理および リスクコミュニケーションの現状
}

渡邉 浩 ${ }^{1}$ 山口一郎 ${ }^{2}$ 木田哲生 ${ }^{3}$ 平木仁史 ${ }^{4}$ 藤淵俊王 $^{5}$ 前原善昭 ${ }^{6}$ 塚本篤子 ${ }^{7}$ 小泉美都枝 ${ }^{8}$ 木村有美 ${ }^{8}$ 堀次元気 ${ }^{9}$

論文受付 2012 年 8 月 29 日

論文受理 2012 年 12 月 29 日 Code No. 633
1 独立行政法人労働者健康福祉機構横浜労災病院 中央放射線部

2 国立保健医療科学院生活環境研究部

3 国立大学法人滋賀医科大学医学部附属病院放射 線部

4 帝京大学医学部附属溝口病院中央放射線部
5 茨城県立医療大学保健医療学部放射線技術科学科

6 聖マリアンナ医科大学病院画像センター

${ }^{7}$ NTT 東日本関東病院放射線部

${ }^{8}$ 川崎市立多摩病院画像診断部

9 大阪大学大学院医学系研究科放射線統合医学講 座核医学

\section{緒 言}

核医学検査や核医学治療に用いられた非密封放射性 同位元素(radioisotope: RI)に由来する放射性廃棄物 は, 臨床検査技師法や薬事法などに基づくものも含 め, 医療機関などが廃棄を公益社団法人日本アイソ
トープ協会 (RI協会)に委託し, RI 協会が集荷してい る. 医療由来の放射性廃棄物は, RI が封入されていた ガラス製のバイアル，RIを患者に投与する際に使用す る針，プラスチック製あるいはガラス製のシリンジ，プ ラスチック製の延長チューブなどである。集荷された医

\section{Current Status on Storage, Processing and Risk Communication of Medical Radioactive Waste in Japan}

\author{
Hiroshi Watanabe, ${ }^{1 *}$ Ichiro Yamaguchi, ${ }^{2}$ Tetsuo Kida,${ }^{3}$ Hitoshi Hiraki, ${ }^{4}$ Toshioh Fujibuchi, ${ }^{5}$ \\ Yoshiaki Maehara, ${ }^{6}$ Atsuko Tsukamoto, ${ }^{7}$ Mitsue Koizumi, ${ }^{8}$ Yumi Kimura, ${ }^{8}$ and Genki Horitsugi ${ }^{9}$ \\ ${ }^{1}$ Department of Radiological Technology, Japan Labour Health and Welfare Organization Yokohama Rosai Hospital \\ ${ }^{2}$ Department of Environmental Health, National Institute of Public Health \\ ${ }^{3}$ Department of Radiological Service, Shiga University of Medical Science Hospital \\ ${ }^{4}$ Department of Radiological Technology, Teikyo University School of Medicine, University Hospital, Mizonokuchi \\ ${ }^{5}$ Department of Radiological Science, School of Health Sciences, Ibaraki Prefectural University of Health Sciences \\ ${ }^{6}$ St.Marianna University Hospital, Medical Imaging Center \\ ${ }^{7}$ Department of Radiology, NTT Medical Center Tokyo \\ ${ }^{8}$ Department of Diagnostic Imaging, Kawasaki Municipal Tama Hospital \\ ${ }^{9}$ Department of Nuclear Medicine and Tracer Kinetics, Osaka University Graduate School of Medicine
}

Received August 29, 2012; Revision accepted December 29, 2012

Code No. 633

\section{Summary}

Decay-in-storage for radioactive waste including that of nuclear medicine has not been implemented in Japan. Therefore, all medical radioactive waste is collected and stored at the Japan Radioisotope Association Takizawa laboratory, even if the radioactivity has already decayed out. To clarify the current situation between Takizawa village and Takizawa laboratory, we investigated the radiation management status and risk communication activities at the laboratory via a questionnaire and site visiting survey in June 2010. Takizawa laboratory continues to maintain an interactive relationship with local residents. As a result, Takizawa village permitted the acceptance of new medical radioactive waste containing Sr-89 and Y-90. However, the village did not accept any non-medical radioactive waste such as waste from research laboratories. To implement decay-in-storage in Japan, it is important to obtain agreement with all stakeholders. We must continue to exert sincere efforts to acquire the trust of all stakeholders.

Key words: radioactive waste, risk communication, decay-in-storage, clearance, Japan Radioisotope Association Takizawa laboratory

*Proceeding author 
療由来の放射性廃衰物は, 岩手県滝沢村と RI 協会の 公害防止協定(協定)に基づくルールを遵守し RI 協会茅 記念滝沢研究所(滝沢研究所)に保管されてきた.

これらの医療由来の放射性廃棄物は用いられる RI の 半減期が短いことから, 欧米 ${ }^{1)}$ や韓国 $^{2}$ では, 減衰待ち 保管(decay in storage: DIS)によるクリアランスを実施し ている。しかしながら, 本邦では医療由来の放射性廃 衰物の処分法は未だ確立していない.

放射性廃衰物をクリアランスするか否か，あるいはど のようにクリアランスするかは経済的な観点でも評価す る必要がある ${ }^{3)}$ 。また, 国民は, 放射能あるいは放射性 廃棄物に対し, その量にかかわらず, 負の印象をもつこ とから，国民の理解を得ることも必要である。したがっ て, 医療由来の放射性廃棄物を今後どのように管理あ るいは処分するかはこれらの因子を総合的に検討し, なおかつ国民と共考する必要がある.

医療由来の放射性廃重物の管理あるいは処分につい て国民と共考するためには，まず医療由来の放射性廃 㶳物の保管, 処理の現状を整理して示す必要がある.

また，滝沢村におけるリスクコミュニケーションの状況 は, 国民全体を対象としたリスクコミュニケーションに とって貴重な知見となる。

そこで, 本邦で唯一, 医療由来の放射性廃棄物を保 管, 処理している滝沢研究所の担当者を対象に施設運 営の現状とリスクコミュニケーションの取り組み状況を 調査したのでその結果を報告する.

なお，ある物質に含まれる微量の放射性物質に起因 する線量が, 自然界の放射線レベルに比較しても十分 小さく, 人の健康への影響が無視できるものであるなら ば，その物質を放射性物質として扱う必要がないものと して，放射線防護に係る規制の枠組みから外すという 考え方を「クリアランス」と定義されている4).

\section{1. 方 法}

滝沢研究所での医療由来の放射性廃棄物の保管, 処 理状況や周辺住民とのリスクコミュニケーションの実態 を調べるために 2010 年 6 月 21 日に滝沢研究所の本調 査の担当となった職員 (担当者)に電子メールにて調査 票を送信し，その回答の返信を依頼した。また，2010 年 6 月 25 日に放射性廃棄物の保管, 処理状況などを訪 問調査した。調査の進渉・解析過程で, 適宜滝沢研究 所の担当者に追加の情報提供を依頼した。

なお，調査票による調査は担当者一人と行ったが, 訪問調査では複数の職員が調査に対応した。また, 調 査票の内容を下記に列挙した.

1) 滝沢研究所に保管している放射性廃棄物の数量, 発

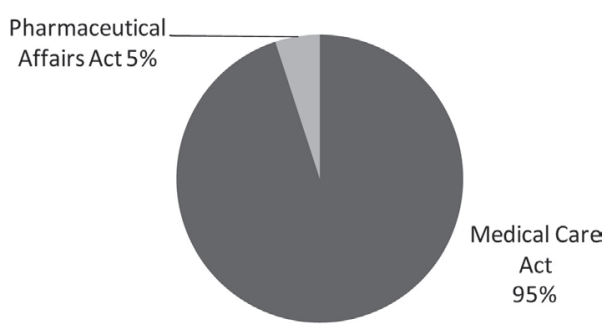

Fig. 1 Composition ratio of radioactive wastes regarding regulations. These wastes were collected at Japan radioisotope association Takizawa laboratory.

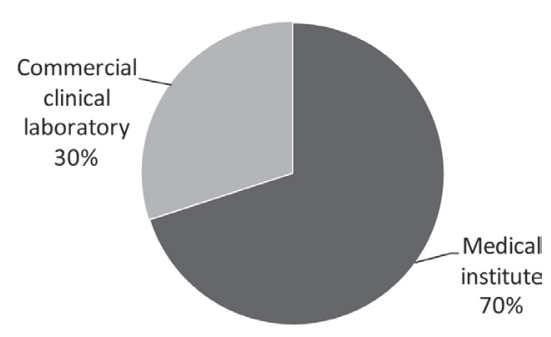

Fig. 2 Source ratio of radioactive wastes relating medical collected at Japan radioisotope association Takizawa laboratory.

生元, 材質別割合, 減容·圧縮容量, 保管スペースの残 量および保管費用

2) 滝沢村との放射性廃棄物に関する協定内容, 集荷基 準および集荷した放射性廃棄物が滝沢研究所に運ばれ るまでの期間

3) 滝沢村および住民との交流あるいはリスクコミュニ ケーションの状況および人体影響に関する説明

4) 滝沢研究所に集荷している放射性廃棄物のクリアラ ンスの可能性

\section{2. 結 果}

\section{2-1 滝沢研究所で保管・処理している放射性廃棄物 の概要}

2009 年度末現在, 滝沢研究所に保管されている放射 性廃衰物は200 リットル，ドラム缶に換算すると約 16,000 本で，協定に基づく所管法令別の発生元は医療 法が約 95\%, 薬事法が約 5\%であった(Fig. 1). 医療法 のうち, 医療機関が実施した核医学検査および治療に

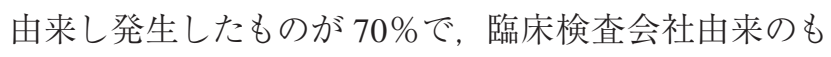
のは30\%であった(Fig. 2)。したがって，医療由来の放 射性廃棄物のみを保管, 処理していることとなる。

滝沢研究所に保管している材質別の放射性廃棄物 は, 処理前の時点で可燃物が 2\%, 難燃物が 33\%, 不 然物が $28 \%$ ，その他フィル夕類が $37 \%$ であった。この 
割合は滝沢研究所のみのデータであるため, 原則年度 ごとに公開されている放射線利用統計とは若干異なって いる。なお，放射線利用統計は RI 協会のホームページ に揭載されるだけで印刷物としては発刊されていない.

滝沢研究所に集荷された放射性廃棄物のうち, 可燃 性および難燃性のものは焼却炉による焼却処理を行 い, 不燃性のものは $200 \mathrm{t}$ のプレス機で圧縮処理を行っ ている。焼却ならびに圧縮による減容率の平均はそれ ぞれ $0.5 \%, 25 \%$ である。放射性廃棄物は, 減容などの 処理をした後, 滝沢研究所に放射性廃棄物として保管 し続けている.

RI 協会が集荷した放射性廃棄物は, 関東地区の貯蔵 所で一時保管した後, 滝沢研究所に輸送される。医療 機関から集荷した後, 滝沢研究所において焼却処理す るまでに約 1 年以上が経過している.

焼却処理前に行っている放射性廃莗物からの放射線 量の測定では，焼却した際に排気中濃度管理基準值(法 定排気中濃度限度の 1/10) を超えると予想される放射線 を検出することはなく, また, 焼却炉のメンテナンス作 業担当者の被ばく線量も滝沢研究所開所以来, 放射線 測定器の検出限界である $0.1 \mathrm{mSv} /$ 月を超えたことはな い。つまり，放射性廃衰物を焼却した炉内に立ち入って メンテナンスを行う作業者であっても焼却炉内がバック グラウンドレベルであることを確認してから作業してい ることもありこれまでに個人線量計で検出可能な程度の 放射線被ばくを受けたことがない.

\section{2-2 滝沢研究所施設内および周辺地域の放射線量}

RI 協会では，滝沢村との協定などに基づき，施設内 および周辺地域の放射線量について，モニタリングポ ストによる空間線量の測定, 熱ルミネッセンス線量計素 子を用いた積算線量の測定, 水, 牧草, 玄米および牛 乳を採取し周辺環境試料としての測定, 滝沢研究所か ら排出する排気・排水中の放射能濃度の測定を行ってい る. これらの值も滝沢研究所開所以来, バックグラウン ドの通常変動範囲を超える異常な放射線や医療由来の 放射性核種を検出したことはない，なお，これらのデー 夕は調査当時は RI 協会のホームページに掲載されてい たが本稿の執筆時点では掲載されていない，また，本 調査結果は, 2011 年 3 月に本邦で発生した東日本大震 災に伴う福島第一原発事故前のものである.

\section{2-3 滝沢研究所での周辺自治体とのリスクコミュ ニケーション}

RI 協会は年 1 回，滝沢研究所を公開し広く住民との 交流を眓っていた。また, 自治会主催の運動会や祭
事, 小中学校主催の行事, 滝沢村や地元商工会による 催事·会合などに参加し周辺自治体，住民との交流に努 めていた.

施設見学は随時受け入れており, また, 滝沢研究所 のパンフレットを作成・配布し, 滝沢研究所の意義や RI の医療利用の重要性の啓発活動を行っていた。また, 滝沢村の広報媒体の活用やリーフレットを滝沢村住民 や近隣市町村住民に配布し情報公開を行っていた，滝 沢村などの周辺住民との空口は担当部署ならびに担当 者を定めて対応しているが，リスクコミュニケーション と位置付けた専門的な知識・技術を習得するための研修 は行っていなかった。

滝沢研究所としては, 直接調査してはいないものの 情報公開や交流を通じて，当初反対していた住民の 方々が滝沢研究所の必要性を認め, 理解を示している ことから, 滝沢研究所について理解度が深まっていると 考えていた。

\section{2-4＼cjkstart新たな放射性廃棄物の受け入れ状況}

滝沢村担当部署に新薬に関する情報提供に努め, 協 議を重ねた結果，医療用として用いられるようになった 2 核種(Sr-89，Y-90)の追加は認められた。しかし，放 射性同位元素などによる放射線障害の防止に関する法 律(障防法)所管の放射性廃棄物の保管を滝沢研究所で 行えるようにすることを滝沢村に 2 度提案していたもの の，いずれも受け入れられなかった。

\section{2-5 その他}

RI 協会が放射性廃棄物として集荷できないものにつ いては RI 協会作成の RI 廃棄物収納基準に示されてい ることを再確認した。また，放射性廃棄物の保管入 ペースは 10 年以上の余力があると考えていた.

また，放射性廃棄物の保管費用，放射性廃棄物に関 するリスクコミュニケーション上のアドバイスならびに今 後, RI 協会でクリアランスしていくことの可能性などに ついては諸事情から具体的に回答をいただけなかった。

\section{3. 考 察}

\section{3-1 滝沢研究所における放射性廃棄物と周辺環境 の状況}

2-2に示したように滝沢研究所による施設内および周 辺地域の放射線量などの測定結果は, 測定の検出限界 の問題はあるものの医療由来の放射性廃棄物をクリアラ ンスすることが可能であることを示唆している. 
Table Recent trend of commission fee for radioactive wastes

\begin{tabular}{lccc}
\hline \hline Classification & Fiscal year & $\begin{array}{c}\text { Fee } \\
\text { (yen/drum) }\end{array}$ & $\begin{array}{c}\text { Relative fee } \\
\text { (compared with 2007, \%) }\end{array}$ \\
\hline Combustibles & 2007 & 25,830 & 15.4 \\
& 2008 & 29,820 & 30.5 \\
Difficult to compress & 2010 & 33,705 & \\
& 2007 & 22,600 & 13.1 \\
Incombustibles & 2008 & 38,010 & 26.3 \\
& 2010 & 42,420 & 5.7 \\
& 2007 & 58,590 & 11.3 \\
\hline
\end{tabular}

*: Maximum volume is 50 liters.

\section{3-2 現在の医療由来放射性廃棄物の管理・処分コス 卜の経済的合理性}

RI 協会は, 放射性廃棄物の集荷, 処理, 保管などの 環境整備事業は支出超過になっていることから, 2007 年に放射性廃棄物の集荷費用を值上げした ${ }^{5)}$ 。この值上 げは, 文部科学省が設置した RI・研究所など廃棄物作 業部会の報告書 $(\mathrm{RI} \cdot$ 研究所など廃棄物作業部会報告 書) ${ }^{6)}$ で, 処分費用の試算值が最終的に埋設される廃棄 体(200 リットル換算) 1 本あたりピット処分で 70 万円と 示され, 協会が 2003 年度の RI 廃棄物料金改定時に採 用した試算值である 41.2 万円に比して大幅な増額と なっていることがその理由の一部になっている，值上げ 率を Table に示す。 2007 年度と比べると 2010 年度では 11.3〜30.5\%の值上げになっている. また, この RI・研 究所など廃棄物作業部会報告書では, 放射性廃棄物の 管理・処分費用の発生元責任を明確化しており, 今後医 療由来の放射性廃棄物の管理・処分コストが上昇すれ ば，医療機関が少なくともその一部を負担することにな るため, 今後も料金が值上げされる可能性がある. 放 射性廃棄物の集荷委託費用はすべて医療機関のコスト であり，何らかのかたちで医療費に反映されることにな る. 木田ら ${ }^{3)}$ によると他の先進国と同様のクリアランス 制度(DIS を含む)を実施することによって年間約 7 億円 の費用削減が見込まれており, クリアランスによって経 済的な合理性に貢献する。

\section{3-3 本邦におけるクリアランスのための準備と手法}

本邦における医療由来の放射性廃棄物の合理的な管 理, 処分とその品質保証制度の確立については検討が 十分に行われており, その適切な実現は十分可能な段 階に来ている7 12). したがって，本邦においてもクリア ランス制度を導入し放射性廃衰物を経済的に合理的な
管理と処分を行うことが可能である.

ただし，本邦の現状を踏まえるとクリアランス制度の 導入方法は二つに大別される。一つは, 欧米や韓国な どと同様に医療機関において一定期間減衰待ち保管を 行いクリアランスする方法である. 二つ目は, 従来同様 に滝沢研究所に集荷した後でクリアランスする方法で ある。二つ目の方法は，集荷時は規制された放射性廃 棄物のままであるため, 搬送コストを現状から大幅に削 減するのが難しいことは容易に推察しうる。木田ら ${ }^{3)}$ の 費用削減の推定も欧米や韓国と同様に医療機関でクリ アランスする方法を前提としている.

\section{3-4 リスクコミュニケーションの現状と課題}

RI 協会では, 地元・地域の住民と積極的に交流を図 り, また, 滝沢研究所の意義と安全性の広報に努めて おり, 当初反対していた住民の方々が滝沢研究所の必 要性を認め, 理解を示していることや医療用として最近 使用されるようになった 2 核種の追加が認められたこと から滝沢研究所において放射性廃䢂物を保管, 処理し ていることの安全性について一定の理解が得られてい ると考えていた。しかし, 今回の調査は滝沢研究所職 員への調査に基づくものであり, 周辺住民の理解度の 評価についてはバイアスが否定できない.

医療用 2 核種の追加は認められたが，障防法所管の 放射性廃棄物を滝沢研究所において扱えるようにする 2 度の提案は受け入れられなかった。医療用核種と障防 法核種の違いは，医療用核種は半減期が短いものに限 定されていることと国民生活に密接に関係する医療目的 であるということの 2 点である. また，十分な理解が得 られていないことの理由として滝沢研究所開設時に賛 成派と反対派で滝沢村住民が二分された過去の経緯 や，周辺に関連工場を誘致する約束が反故にされたこ 
とが根底にある可能性が伺われる13). リスクコミュニ ケーションとは，米国国立研究審議会によれば，利害関 係者間のリスクに関する情報と意見の交換による相互 作用とされ14)，また，木下によれば，対象のもつリスク に関する情報を当該りスクの関係する人々(ステークホ ルダ)に対して可能な限り開示し，たがいに共考するこ とによって解決に導く道筋を探す社会的技術のこととさ れている15)。リスクコミュニケーションは周辺住民(ス テークホルダ)の理解を得ることを直接の目的とせず， 説明者側の意図を実現することを目指すものでもない が，社会問題の健全な解決のためにその手法が活用さ れている。

経済的に合理性のあるクリアランス制度を進渉させ るためには「医療」，「短半減期」の核種からクリアランス 制度が適用されていく可能性が考えられる.

しかし，クリアランス制度などを取り入れるための改 正障防法では，核原料物質，核燃料物質及び原子炉の 規制に関する法律(原子炉等規制法)のクリアランス制 度において既に認可されていた金属くず，コンクリート 片およびガラスくず以外の放射性廃棄物については, 可燃物の焼却灰以外はクリアランスが認められなかっ た。事業所ごとに焼却炉を設置することは経済的に困 難であり事実上事業所ごとの可然物のクリアランスは実 現不可能になった。 また，原子炉等規制法では上記 3 種類の廃棄物のクリアランスが認められベンチなどに再 利用されているが関連事業所が引き取っており一般社 会ならびに国民に受け入れられている状況にはない16). したがって，焼却しない可燃物のクリアランスを実現す るためには関係者の国民からの信頼を獲得するための 努力がさらに求められる.

本論文は，医療由来放射性廃肓物の合理的な管理， 処分を実現する観点から調査検討を行ったが，RIの利 用は科学技術の発展や国民生活の安全性の担保などに も役立っており, 発生する比較的長半減期の放射性廃 衰物の管理と処分のあり方についても国民と共考するこ とが必要である。

\section{4. まとめ}

医療由来の放射性廃棄物の管理あるいは処分につい て国民と共考するために本邦で唯一，医療由来の放射 性廃棄物を管理している滝沢研究所における放射性廃
衰物の保管・処理およびリスクコミュニケーションの現 状を調査した。

滝沢研究所が実施している測定では，開所以来，異 常な放射線あるいは医療由来の核種を検出していな かった。これらの結果から医療由来の放射性廃棄物を クリアランスすることが可能であることが示唆された。 本邦における医療由来の放射性廃棄物の合理的な管 理，処分とその品質保証制度の確立については検討が 十分に行われており，その適切な実現は十分可能な段 階に来ている. RI 協会の放射性廃衰物の集荷，処理， 保管などの環境整備事業は支出超過になっており，経 済的な合理性に貢献するためにはクリアランス制度 （DIS を含む）を実施することが求められる。滝沢研究所 は周辺住民との交流，情報公開を積極的に行っており 一定の成果が得られていた。すべてのステークホルダ の理解を得るためには，「医療」，「短半減期」の核種か らクリアランス制度を適用していくとともに関係者の更 なる努力が求められる.

\section{謝 辞}

医療由来の放射性廃棄物は現行法令にしたがえば, 半永久的に放射性廃棄物であり，処分先が決まってい ない現状ではどこかに保管せざるを得ない，その放射 性廃棄物を滝沢研究所において開設当初から今日まで 保管させていただいていることに，滝沢村の皆様に心 から感謝申し上げます。

また，本稿の執筆にあたり訪問を快諾賜わり，また， 調査にもご協力いただいた RI 協会ならびに滝沢研究所 の皆様，そして滝沢研究所訪問にご協力いただいた神 奈川核医学研究会の皆様に心から感謝申し上げます。 さらに, ご指導いただいた鈴鹿医療科学大学大学院 鎮 西康雄教授，土屋 仁教授に感謝申し上げます。

なお，本研究は，公益社団法人日本放射線技術学会 平成 22 年度および平成 23 年度学術調査「放射性廃棄 物のリスクコミュニケーション等に関する研究」班の研 究活動の一環として行った。また，同学会学術交流委 員会関係法令等検討小委員会の支援を受けた.

本研究は, 同学会第 39 回秋季学術大会(平成 23 年，神戸)において発表した。 


\section{参考文献}

1) 戸川貴史, 橋本 順, 百瀬 満. 欧米諸国の法令研究及び 実態調査. 平成 15 年度厚生科学研究費補助金報告書 (医薬 安全総合研究事業)「医療行為に伴い排出される放射性廃棄 物の適正管理に関する研究」総括・分担研究報告書. 2004: 145-154.

2) 渡辺 浩, 長岡宏明, 山口一郎, 他。韓国に抢ける医療利 用に伴う放射性廃棄物の管理と処分の実施状況調査. 日放 技学誌 2009; 65(7): 952-957.

3) 木田哲生, 平木仁史, 山口一郎, 他. 核医学診療施設が排 出する RI 污染物の減衰保管の実現による廃棄処分の費用 削減効果の推定．日放技学誌 2012; 68(4): 468-474.

4) 文部科学省科学技術・学術政策局 放射線安全規制検討 会. 文部科学省ホームページ，放射線障害防止法へのクリ アランス制度の導入に向けた技術的検討結果について(第 2 次中間報告書)http://www.mext.go.jp/component/b_menu/ shingi/toushin/__icsFiles/afieldfile/2012/03/27/1290221_1. pdf

5) 日本アイソトープ協会：RI 廃棄物料金改定のお知らせ。 ISOTOPE NEWS 2007; 640: 44-46.

6) 原子力分野の研究開発に関する委員会·RI 研究所等廃棄物 作業部会：「RI - 研究所等廃棄物作業部会報告書」. 文部科 学省ホームページ http://www.mext.go.jp/b_menu/shingi/ gijyutu/gijyutu2/shiryo/012/06110922/001.htm

7）日下部きよ子。「医療行為に伴い排出される放射性廃棄物の 適正管理に関する研究」. 平成 14 年度厚生労働科学研究費 補助金(医薬安全総合研究事業)総括・分担研究報告書. 2003.

8）日下部きよ子.「医療行為に伴い排出される放射性廃棄物の 適正管理に関する研究」. 平成 15 年度厚生労働科学研究費 補助金(医薬安全総合研究事業) 総括. 分担研究報告書. 2004.
9）日下部きよ子．医療放射性廃棄物のクリアランスに関する研 究. 平成 16 年度厚生労働科学研究費補助金(医療技術評価 総合研究事業)「医療放射線分野に打ける法令整備等含めた 管理体制の確立に関する研究」総括・分担研究報告書. 2005 .

10）日下部きよ子．医療放射性廃棄物のクリアランスに関する研 究. 平成 17 年度厚生労働科学研究費補助金(医療技術評価 総合研究事業)「医療放射線分野における法令整備等含めた 管理体制の確立に関する研究」総括・分担研究報告書. 2006.

11）文部科学省放射線安全規制検討会：放射線障害防止法に扮 けるクリアランス制度の整備に係る技術的検討について(中 間報告書)。2006. 文部科学省ホームページ http://www. mext.go.jp/b_menu/shingi/chousa/gijyutu/004/004/ shiryo/_icsFiles/afieldfile/2009/05/21/20060629_01b.pdf

12）木田哲生，山口一郎，渡辺 浩，他. 医療用短半減期核種 の放射性廃棄物の適正な管理に向けての文献的考察. 日放 技学誌 2009; 65(5): 631-637.

13）大越 実，鳥井弘之，藤井靖彦．放射性廃棄物管理施設の 立地に拈けるリスクコミュニケーション。 日本原子力学会和 文論文誌 2007; 6(4): 421-433.

14) National research Council: Improving Risk Communication. National Academy Press(1989)(林 祐造, 関沢 純 監訳.リスクコミュニケーションー前進への提言)。東京： 化学工業日報社, 1997.

15）日本保健物理学会・リスクコミュニケーション検討研究会： 保健物理学会員のためのリスクコミュニケーション講座(そ の 1). 日本保健物理学会ホームページ, http://wwwsoc.nii. ac.jp/jhps/j/groups/spec_riskcom/risk_kouza1.pdf.

16）参議院 文教科学委員会 10 号 平成 22 年 04 月 27 日議事 録. 参議院議事録ホームページ. http://www.sangiin.go.jp/ japanese/joho1/kaigirok/kaigirok.htm

問合先 